\title{
BEATA GROCHALA-WOŹNIAK
}

Uniwersytet Łódzki, Wydział Filologiczny, Instytut Filologii Polskiej, Katedra Lingwistyki Stosowanej i Kulturowej

\section{(Dez)informacja w korespondencji handlowej}

Współczesny człowiek nazywany jest homo communicans. To istota niejako zaprogramowana na komunikowanie się z innymi, w ten sposób określająca swoje jestestwo. Jak pisze Marian Golka, ,bez komunikowania nie byłoby człowieka, społeczeństwa kultury" [Golka 2008:4]. Komunikujemy się w każdej sytuacji, za pomocą rozmaitych mediów, na każdy temat. Wydaje się jednak, że w tym pędzie komunikacyjnym zatracamy samą istotę zjawiska, jaką jest wymiana informacji ${ }^{1}$. Jest to pewien paradoks, bowiem w sytuacji ciągłego zabiegania, pośpiechu, powszechnego braku czasu nasza komunikacja powinna stawać się jak najbardziej precyzyjna, prowadzona według jasnych, ściśle określonych reguł. Zasady te można by odnieść przede wszystkim do tzw. komunikacji oficjalnej, która w opozycji do komunikacji prywatnej ma służyć przede wszystkim wymianie informacji, w mniejszym zaś stopniu budowaniu więzów społecznych, relacji itp. Przykładem może być tu korespondencja handlowa.

Chcąc zaklasyfikować ją do jednego ze stylów współczesnej polszczyzny, powinno się wskazać na styl urzędowy, który w literaturze językoznawczej doczekał się licznych opracowań. Warto wspomnieć choćby prace Ewy Malinowskiej [np. Malinowska 2001; Malinowska 2004] czy Marii Wojtak [por. Wojtak 2001; Wojtak 2004]. Styl ten charakteryzowany jest przez pryzmat działalności administracyjno-prawnej, głównie w odniesieniu do jego dyrektywności. Niezmiennie powtarzanymi cechami są: bezosobowość, szablonowość, dyrektywność i precyzyjność. Typowy jest dla niego „oficjalny, pozbawiony więzi emocjonalnej kontakt między partnerami porozumienia” [Zdunkiewicz-Jedynak 2008: 159].

\footnotetext{
${ }^{1}$ Przez zdecydowaną większość badaczy przekaz informacji uznawany jest za najważniejszą funkcję komunikacji, choć wymienia się także takie, jak: pomoc w zrozumieniu siebie i innych, pomoc w zrozumieniu kultury i świata fizycznego, oddziaływanie na innych, tworzenie łączności z innymi ludźmi, tworzenie interakcji i koordynacja działań, gromadzenie i przekaz doświadczeń oraz treści pamięci społecznej, tworzenie kultury (por. Golka 2008: 4).
} 
Warunek ten spełnia bez wątpienia korespondencja handlowa, brakuje w niej również styczności czasowej i przestrzennej nadawcy i odbiorcy, a także uwidacznia się nierówność ról komunikacyjnych, co stanowi kolejne wyznaczniki stylu urzędowego. Wśród typowych dla tej warstwy polszczyzny gatunków wymienia się: konstytucję, ustawę, dekret, rozporządzenie, regulamin, dekret, ankietę, życiorys, metrykę urodzenia, akt zgonu, zeznanie podatkowe i inne. Dorota Zdunkiewicz-Jedynak wspomina także o specyficznej grupie gatunków w obrębie stylu urzędowego, jakimi są gatunki korespondencyjne, a wśród nich korespondencja biurowa, listy handlowe, okólniki, oferty, zamówienia, umowy, protokoły, monity, reklamacje, odpowiedzi na reklamacje, listy intencyjne [Zdunkiewicz-Jedynak 2008: 166].

O korespondencji handlowej jako specyficznym typie komunikacji odbywającym się w obrębie stylu urzędowego mówi się niewiele w porównaniu do „klasycznych” gatunków urzędowych. Zagadnienie to przykuwa raczej uwagę specjalistów z zakresu marketingu, zarządzania, w mniejszym zaś stopniu językoznawców. Tymczasem okazuje się, że jest to znakomity materiał właśnie do badań lingwistycznych. Powodów tego jest kilka. Po pierwsze, współczesna korespondencja handlowa wykorzystuje w dużej mierze wymienione wcześniej gatunki. Po drugie, można postawić tezę, iż dochodzi w niej do zaburzenia kanonicznych cech stylu urzędowego, co łączy się bezpośrednio z funkcją tych tekstów.

Celem niniejszego artykułu jest analiza tekstów korespondencji handlowej pod kątem ich informacyjności/dezinformacyjności. Korpus badawczy stanowiły głównie odpowiedzi na reklamacje, w mniejszym stopniu zindywidualizowane oferty handlowe i pisma dotyczące wypowiedzenia umowy. W sumie było to ponad 100 pism, zarówno tradycyjnych, jak i elektronicznych. Wszystkie powstały $\mathrm{w}$ jednej firmie ${ }^{2}$, jednak wyniki badań zostały porównane z co prawda niewielką, bo liczącą każdorazowo około 10 tekstów, grupą pism pochodzących z dwóch innych firm porównywalnej wielkości³

Odpowiedź na reklamację jest specyficznym typem tekstu o dość skodyfikowanej, trójdzielnej strukturze. Każdorazowo powinna zawierać: informację o rozpatrzeniu/nierozpatrzeniu reklamacji, uzasadnienie, formułę grzecznościową. W wersji minimalnej odpowiedź na reklamację może ograniczyć się do pierwszego członu, jednak zasady etykiety w korespondencji handlowej wymagają, aby obecne były także dwa pozostałe segmenty. W pierwszym członie należy podać krótką, jednozdaniową informację wg wzoru: Informujemy, że Państwa/Panal Pani reklamacja $n r . .$. /z dnia.... /dotyczaca .... została uznana za zasadna/bezzasadna. Jest to wypowiedzenie szablonowe, o charakterze czysto informacyjnym.

${ }^{2}$ Firma jest częścią dużego koncernu europejskiego o charakterze usługowo-handlowym. Jej centrala znajduje się w Łodzi, jednak przedstawicielstwa znajdują się w kilku miejscach w Polsce.

${ }^{3}$ Firmy te mają zupełnie różny profil, jednak każda z nich ma charakter usługowy bądź handlowy, stąd pojawiające się często reklamacje i odpowiedzi na nie. 
Zdecydowanie bardziej rozbudowany jest człon drugi, uzasadnienie, zwłaszcza w przypadku reklamacji bezzasadnej. Powinien on w sposób jasny, zrozumiały dla odbiorcy informować o przyczynach odmowy bądź wskazywać na powód powstania błędu. Należy go skonstruować w taki sposób, aby odbiorca czuł się usatysfakcjonowany, a jednocześnie wzmocnił swoje zaufanie do firmy. Ostatni element, formuła grzecznościowa, to typowe dla korespondencji handlowej zwroty pożegnalne wraz z podpisem osoby odpowiadającej na reklamację.

Już ta wstępna charakterystyka pokazuje, że mamy do czynienia z tekstem, który z założenia powinien być informacją. Klient po zapoznaniu się z odpowiedzią na reklamację powinien znać powód powstania niedogodności oraz wiedzieć, jakie środki przedsięwzięto, aby zapobiec danej sytuacji w przyszłości (oczywiście, jeśli reklamacja była zasadna) lub znać powód nieuznania skargi, $\mathrm{np.:} \mathrm{Uprzejmie} \mathrm{informuję,} \mathrm{że} \mathrm{składana} \mathrm{przez} \mathrm{Państwa} \mathrm{reklamacja} \mathrm{dotycząa} \mathrm{jako-}$ ści dostarczonego czyściwa została uznana za zasadna. W dniu 28.02.2013 zareklamowany kontener z czyściwem zostanie wymieniony na nowy. Sprawa została również przekazana do naszego dostawcy w celu omówienia z nim odpowiedniego standardu produktu 4 .

W analizowanym materiale takie teksty stanowią jednak zdecydowaną mniejszość. Czytając większość odpowiedzi na reklamację, ma się wrażenie, że ich celem nie jest informacja, lecz dezinformacja prowadzona w sposób jak najbardzej świadomy, choć nieuświadamiany klientowi. Pozornie otrzymuje on pismo spełniające wszystkie standardy gatunku, jednak po dokładnej analizie okazuje się, że z owego tekstu nic nie wynika. Autorzy odpowiedzi na reklamację, pracownicy działu obsługi klienta, mają bowiem opracowane pewne szablony odpowiedzi, z których korzystają nader często, a ich wkład twórczy w sformułowanie odpowiedzi ogranicza się do podania numeru reklamacji.

Do najczęściej używanych należy zdanie: Artykuł został oznaczony do szczegółowej kontroli. Pozornie jest to wypowiedzenie o charakterze informacyjnym, z którego dowiadujemy się, że... właśnie, właściwie nie dowiadujemy się niczego, gdyż kluczowe sformułowanie oznaczony do kontroli nie zawiera żadnych konkretów. Zgodnie z definicją słownikową oznaczyć to «1. być znakiem czegoś, wyrażać jakąś treść; 2. zrobić (robić) na czymś znak, opatrzyć (opatrywać) coś znakiem; zaznaczyć (zaznaczać); 3. wyrazić (wyrażać), określić (określać) za pomocą znaku; 4. wybrawszy ustalić (ustalać), wyznaczyć (wyznaczać) coś» [USJP]. Wydaje się, że w analizowanym przykładzie mamy do czynienia z drugim odcieniem semantycznym, a mianowicie 'zrobić na czymś znak'. Jeśli jednak dokonamy takiej interpretacji, wówczas okaże się, że jedynym działaniem podjętym przez firmę było zaznaczenie, że towar ma być sprawdzony. Jednak tak nie jest,

${ }^{4} \mathrm{~W}$ prezentowanych przykładach nie wprowadzano żadnych zmian. W niniejszym opracowaniu nie podjęto również problematyki poprawności językowej analizowanego materiału, gdyż nie było to celem badawczym. 
ale odbiorca tekstu nie może o tym wiedzieć, zwłaszcza w początkowym okresie kontaktu z firmą. Ów oznaczony dotyczy tu informacji, jaka została wprowadzona w systemie komputerowym firmy, na podstawie której osoby dokonujące kontroli towarów dany egzemplarz poddadzą szczegółowej ocenie. W tym nieco zagmatwanym wyjaśnieniu pojawiło się słowo kluczowe dla wszystkich omawianych tekstów. Jest to system. Czytamy bowiem: Zgodnie z systemem odzież zostata skierowana na dostawę; Nasz system rejestruje każdy ruch odzieży; W systemie nie ma tej sztuki; System nie wykazal nieprawidtowości; Na podstawie systemu dokonaliśmy wysytki $w$ dniu 02.05.20013. I tu ponownie zacytowane fragmenty odpowiedzi na reklamację pozornie informują, a klient może dowiedzieć się, że system jest odpowiedzialny za wszystko. Rodzi się jednak pytanie, czym ów system jest w rzeczywistości. Najbardziej prawdopodobne wydaje się, że jest to jakiś system komputerowy, za pomocą którego prowadzona jest ewidencja towaru. W rzeczywistości sprawa jest bardziej złożona. Istnieje co prawda skomplikowany system komputerowy związany $\mathrm{z}$ funkcjonowaniem towaru w obrębie firmy, rejestrujący wszystkie informacje o towarze, ale system to także osoba, która przyjmuje/wydaje towar, to osoba odpowiedzialna za sprawdzenie jakości wykonanej usługi, to także półka, na której magazynowany jest towar, samochód, którym jest dostarczany itp. Słowem system jest wszystkim i tak naprawdę niczym. Skąd zatem taka popularność owego systemu?

Tu pojawia się problem najważniejszy dla niniejszych rozważań. Można pokusić się o stwierdzenie, że odpowiedzi na reklamacje są typem tekstu manipulacyjnego i perswazyjnego. Przyjmując za Krzysztofem Szymankiem najbardziej podstawową definicję perswazji jako ,świadomego użycia znaków i symboli, a zwłaszcza pisanego i mówionego słowa, obrazu itp. w celu wywarcia wpływu na czyjeś przekonania, postawy i decyzje, zdobycia czyjejś akceptacji do proponowanych poglądów, sposobów zachowania, decyzji” [Szymanek 2005: 228], możemy stwierdzić, że celem analizowanych tekstów jest głównie zmiana postawy klienta, czyli zapewnienie go o wysokiej jakości usług, przekonanie o niezawodności firmy, a jeśli nawet pojawiają się błędy, to odpowiedzialny za nie jest... system. Mamy tu do czynienia $\mathrm{z}$ tzw. teorią dysonansu poznawczego, czyli pewną sprzecznością pomiędzy zachowaniem a poglądami jednostki. Za Mirosławem Korolką wyodrębnić można trzy rodzaje dyskursu perswazyjnego: przekonywanie (celem jest zmiana postawy), propagandę (cel to pozyskanie zwolenników) $i$ agitację (cel to nakłonienie do działania) [Korolko 1998: 34-35]. W analizowanym przypadku występuje przede wszystkim przekonywanie.

Grażyna Habrajska wyróżnia tzw. perswazję zewnętrzną, której celem jest przygotowanie odbiorcy do perswazji właściwej. Na tym etapie „nadawca musi mieć świadomość, jaką wiedzą o obiekcie perswazji dysponuje odbiorca i jaki jest jego emocjonalny stosunek do tegoż obiektu" (Habrajska 2005: 110). W opisywanej sytuacji komunikacyjnej dodatkowo należy podkreślić nierównorzędny 
charakter ról nadawczo-odbiorczych, oparty przede wszystkim na wspomnianym już dysonansie głównie w zakresie posiadanej wiedzy Nadawca zna dokładnie cały proces technologiczny, wie, jak przebiegają poszczególne etapy usługi, wie wreszcie, czym jest system. Tymczasem odbiorca posiada tę wiedzę tylko w niewielkim zakresie - takim, jaki otrzymał od nadawcy wcześniej, np. przy zawieraniu umowy. Wie, że w firmie funkcjonuje system, ale jest to dla niego słowo semantycznie puste, choć jednocześnie ma świadomość jego dużego znaczenia dla sprawy. Można zatem stwierdzić, że system to słowo-wytrych, którego celem nie jest informowanie, ale wpływanie na odbiorcę. Podobnych słów odnajdziemy w badanym materiale więcej, są to np. skan, skanować i ich derywaty: Reklamowana odzież zostata zeskanowana; Nasz system rejestruje każdy skan odzieży, dlatego w tym przypadku widnieje skan z lipca; Na podstawie skanu odzieży uznano reklamację za niezasadna. Skanować wg słownika to «wprowadzać do komputera tekst, ilustrację, mapę itp. za pomocą skanera» [USJP]. Podchodząc do problemu w sposób linearny, można by stwierdzić, że na podstawie zeskanowania odzieży, czyli de facto zrobienia jej zdjęcia, stwierdzono, że reklamacja jest nieuzasadniona. Tymczasem skan/skanowanie łączy się ze sczytywaniem danych zapisanych w kodzie kreskowym, którym opatrzona jest odzież. I tu znów brak znajomości procedur przyjętych w firmie powoduje, że komunikat nie informuje, lecz dezinformuje, gdyż klient najpierw dokonuje konceptualizacji skanera i procesu skanowania zgodnie ze swoim systemem znaczeń.

Przykłady podobnych niekonsekwencji, wieloznaczności, niedomówień, dezinformacji można by mnożyć. Do najbardziej typowych słów-wytrychów należą: krótka linia produkcyjna (Państwa odzież będzie opracowywana na krótkiej linii produkcyjnej); sklasyfikować (Reklamowana odzież została sklasyfikowana); wznowienie (Odzież po wznowieniu nie została wystana) i wreszcie swoisty majstersztyk - rotować (Reklamowane spodnie rotuja; Nierotujace od marca ogrodniczki zostały zdjęte ze stanu). Czasownika rotować nie odnotowuje słownik Dubisza (ani wcześniejsze), odnajdujemy go w internetowym słowniku PWN, gdzie definiowany jest jako 'obracać się wokół własnej osi'. Wspomniany już USJP notuje natomiast rzeczownik rotacja, a jako podstawowe znaczenia podaje: «krążenie czegoś; obieg, cyrkulacja», np. Rotacja towarów w sklepie [USJP]. Należy przypuszczać, że autorowi owego niefortunnego sformułowania spodnie rotują chodziło o jakiś cykl technologiczny związany z praniem spodni i dostarczaniem ich do klienta, jednak ponownie odbiorca nie jest informowany o konkretnej sytuacji, musi sam dociekać znaczenia, a i to, do którego dojdzie, nie zawiera żadnych konkretnych ustaleń co do istoty reklamacji.

Powraca zadane już wcześniej pytanie, jaki sens ma stosowanie tego typu wyrażeń w korespondencji kierowanej do klienta. Golka pisze, że jedną z najczęstszych przyczyn kłopotów komunikacyjnych jest „nieprecyzyjność znaczeń składników wysyłanego komunikatu" [Golka 2008: 45]. Podkreśla, że najczęściej 
wynika to z naturalnej nieostrości używanych wyrazów, jednak ten sam autor zaznacza, że „współcześnie mamy do czynienia z niedoinformowaniem, przeinformowaniem albo z informowaniem o sprawach nieważnych i drugorzędnych czy wręcz szkodliwych, jak również ze świadomym dezinformowaniem - czyli kłamstwem lub manipulowaniem" [Golka 2008: 111]. Jerzy Bralczyk twierdzi, że „o ile za manipulację nie uznaje się zwykłego kłamstwa [...], to powszechnie do językowych działań manipulacyjnych zalicza się naruszanie podstawowych reguł obowiązujących w komunikacji, jak np. celowe używanie formuł uniemożliwiających falsyfikację sądów, tendencyjne stosowanie nieostrych pojęć, zestawianie informacji w celu uzyskania efektu podobieństwa lub kontrastu, wyolbrzymianie lub pomniejszanie skali zjawisk, a zwłaszcza zacieranie granic między rzetelnym obiektywnym opisem i subiektywną oceną" [Bralczyk 2004: 246]. Można zatem pokusić się o stwierdzenie, że w opisywanej sytuacji komunikacyjnej mamy do czynienia nie tyle z perswazją, co z manipulacją, bowiem komunikat ma wpłynąć na postawy odbiorców przy założeniu nieznajomości stosowanych przez nadawcę zabiegów.

I rzeczywiście, klienci nie uświadamiają sobie wszystkich tych procesów, więcej - nie zwracają uwagi na słowa-wytrychy i nie zastanawiają się nad ich znaczeniem. Nadawca, aby osiągnąć swój cel, musi stale dążyć do wygaszania u odbiorcy pewnej wrażliwości na znaczenia słów. Dzięki temu łatwiej wywrzeć wpływ na klienta. Służą temu owe słowa-wytrychy powtarzane wielokrotnie zarówno w obrębie jednego listu, jak i w całej korespondencji. Opisując przyczyny zaburzeń komunikacyjnych prowadzących do dezinformacji, Golka wymienia manipulację rozumianą jako „oddziaływanie komunikacyjne, które zachodzi przy zamierzonym (najczęściej świadomym) przez nadawcę wyłączeniu krytycyzmu u odbiorcy" [Golka 2008: 39]. Jednym ze sposobów takiego oddziaływania są klisze językowe - ,pewne instrumentalne elementy języka stosowane przez nadawcę maskujące jakieś stany rzeczy, których ujawnienie [...] doprowadziłoby do przekonań odbiorcy niezgodnych z oczekiwaniami nadawcy. [...] Nie tyle zmuszają one do określonych przekonań i zachowań, ile „namawiają” [Golka 2008: 39]. Z taką sytuacją mamy do czynienia w analizowanym przypadku. System, rotacja itp. to właśnie pewne klisze językowe, używane przede wszystkim w celu niedoinformowania odbiorcy przy jednoczesnym budowaniu pozytywnego wizerunku firmy.

John Lyons w Semantyce [Lyons 1984] podkreśla, że znaczenie i rozumienie odpowiadają sobie i oba wymagają intencji. Znaczenie wypowiedzi wymaga intencji komunikatywnej nadawcy, a jej zrozumienie - rozpoznania tej intencji przez adresata. Wydaje się, że ta zależność ulega w badanych tekstach zawieszeniu, a może raczej pewnemu przemodelowaniu. Intencją komunikatywną nadawcy nie jest bowiem osiągnięcie zrozumienia przez adresata, poinformowanie go $\mathrm{o}$ istocie sprawy. Przeciwnie - intencją nadawcy jest niepoinformowanie odbior- 
cy, niepodanie właściwego uzasadnienia. Rodzi się pytanie, czy jest to intencja komunikatywna - raczej nie, stąd powołanie się na teorię perswazji czy manipulacji. Może pojawić się wątpliwość, czy mamy tu do czynienia z perswazją, czy jednak należałoby mówić o manipulacji. Habrajska twierdzi, że cechą różniącą te dwa typy działań jest fakt, iż w manipulacji odbiorca nie jest przygotowany do przyjmowania tez nadawcy, zaś nadawca nie uświadamia odbiorcy swojego pragmatycznego celu, próbuje go maskować albo wskazywać na inny cel niż faktyczny [Habrajska 2005: 120]. Granica jest jednak bardzo płynna i trudno o wyraźne wyznaczenie linii demarkacyjnej. Aby zachować pewną spójność wywodu, należy przyjąć argumentację Szymanka, który, pisząc o wspomnianej wcześniej teorii dysonansu poznawczego, zaznacza, że może ona stanowić ,jedno z najważniejszych narzędzi manipulacji” [Szymanek 2005: 229].

Na zakończenie powróćmy do opozycji słów-kluczy i słów-wytrychów. Te pierwsze ułatwiają nam zrozumienie dyskursu, stają się przewodnikami po tekście, otwierają znaczenia. Słowa-wytrychy to ich antonim, podstępem wkradają się do naszej świadomości, nie pozostawiając po sobie porządku i harmonii, lecz raczej chaos i wątpliwości, ów dysonans, z którym musimy poradzić sobie sami. A my najczęściej przechodzimy obok nich obojętnie, więcej, traktujemy je jak słowa-klucze, mimo że nimi nie są. Powód? Może umiejętna perswazja, czy manipulacja, a może nasza dusza hominis communicantis nie potrzebuje informacji, a wystarcza jej sam proces komunikacji, może nie stanowi dla nas różnicy, czy otwieramy drzwi kluczem czy wytrychem?

\section{Bibliografia}

Bralczyk J. [2004], Manipulacja językowa, [w:] Z. Bauer, E. Chudziński (red.), Dziennikarstwo $i$ świat mediów, Universitas, Kraków.

Golka M. [2008], Bariery w komunikowaniu i społeczeństwo (dez)informacyjne, Wydawnictwo Naukowe PWN, Warszawa.

Habrajska G. [2005], Nakłanianie, perswazja, manipulacja językowa, „Acta Universitatis Lodziensis. Folia Litteraria Polonica", nr 7.

Korolko M. [1998], Sztuka retoryki (przewodnik encyklopedyczny), Wiedza Powszechna, Warszawa.

Lyons J. [1984], Semantyka, Wydawnictwo Naukowe PWN, Warszawa.

Malinowska E. [2004], Wzorce wypowiedzi urzędowych a ich realizacja, [w:] E. Malinowska (red.), Język. Prawo. Społeczeństwo, Wydawnictwo Uniwersytetu Opolskiego, Opole.

Malinowska E. [2001], Wypowiedzi administracyjne - struktura i pragmatyka, Wydawnictwo Uniwersytetu Opolskiego, Opole.

Szymanek K. [2005], Sztuka argumentacji. Słownik terminologiczny, Wydawnictwo Naukowe PWN, Warszawa.

Uniwersalny słownik jezzka polskiego [2003], S. Dubisz (red.), Wydawnictwo Naukowe PWN, Warszawa.

Wojtak M. [2001], Styl urzędowy, [w:] J. Bartmiński (red.), Współczesny język polski, Wydawnictwo Uniwersytetu Marii Curie-Skłodowskiej, Lublin. 
Wojtak M. [2004], Gatunki urzędowe na tle innych typów piśmiennictwa użytkowego-zarys problematyki, [w:] E. Malinowska (red.), Język. Prawo. Spoleczeństwo, Wydawnictwo Uniwersytetu Opolskiego, Opole.

Zdunkiewicz-Jedynak D. [2008], Wyklady ze stylistyki, Wydawnictwo Naukowe PWN, Warszawa. www.sjp.pwn.pl [dostęp 02.08.2013]. 